\title{
World Workshop on Oral Medicine VII: Relative Frequency of Oral Mucosal Lesions in Children, a Scoping Review
}

\begin{tabular}{|c|c|}
\hline $\begin{array}{l}\text { Corresponding } \\
\text { Author }\end{array}$ & $\begin{array}{l}\text { Catherine HL Hong } \\
\text { Discipline of Orthodontics and Paediatric Dentistry } \\
\text { Faculty of Dentistry, National University of Singapore, Singapore } \\
\text { Tel: +65 } 67795555 \text { ext } 1787 \\
\text { Email: denchhl@nus.edu.sg }\end{array}$ \\
\hline \multirow[t]{8}{*}{ Co-authors } & $\begin{array}{l}\text { David R. Dean } \\
\text { Department of Oral Medicine } \\
\text { University of Washington School of Dentistry, United States of America } \\
\text { Tel: }+12062215187 \\
\text { Email: ddean2@uw.edu }\end{array}$ \\
\hline & $\begin{array}{l}\text { Katrusha } \underline{\text { Hull }} \\
\text { Department of Oral Medicine } \\
\text { The Royal Dental Hospital of Melbourne, Australia } \\
\text { Tel: +64 } 0393411000 \\
\text { Email: katrusha.hull@dhsv.org.au }\end{array}$ \\
\hline & $\begin{array}{l}\text { Hu Shi Jia } \\
\text { Discipline of Orthodontics and Paediatric Dentistry } \\
\text { Faculty of Dentistry, National University of Singapore, Singapore } \\
\text { Tel: }+6567795555 \text { ext } 1682 \\
\text { Email: denhus@nus.edu.sg }\end{array}$ \\
\hline & $\begin{array}{l}\text { Sim Yu Fan } \\
\text { Faculty of Dentistry, National University of Singapore, Singapore } \\
\text { Tel: +65 } 67795555 \text { ext } 5970 \\
\text { Email: simyufan@nus.edu.sg }\end{array}$ \\
\hline & $\begin{array}{l}\text { Christine Nadeau } \\
\text { Faculté de médecine dentaire de l'Université Laval, Canada } \\
\text { Tel : +1 } 4186562131 \\
\text { Email : christine.nadeau@fmd.ulaval.ca }\end{array}$ \\
\hline & $\begin{array}{l}\text { Sandra Gonçalves } \\
\text { Department of Oral Medicine } \\
\text { Sheffield Teaching Hospitals, United Kingdom } \\
\text { Tel: +44 } 01142717800 \text { ext } 65488 \\
\text { Email: sandra.goncalves@sth.nhs.uk }\end{array}$ \\
\hline & $\begin{array}{l}\text { Giovanni Lodi } \\
\text { Dipartimento di Scienze Biomediche, Chirurgiche e Odontoiatriche } \\
\text { Università degli Studi di Milano, Italia } \\
\text { Tel: + } 390250319021 \\
\text { Email: giovanni.lodi@unimi.it }\end{array}$ \\
\hline & $\begin{array}{l}\text { Tim A. Hodgson } \\
\text { Oral Medicine } \\
\text { Eastman Dental Hospital } \\
\text { London, United Kingdom } \\
\text { Tel: }+4402034562304 \\
\text { Email: tim.hodgson@ucl.ac.uk }\end{array}$ \\
\hline
\end{tabular}




\section{Abstract (Word Count: 203 words)}

Objective: To detail a scoping review on the global and regional relative frequencies of oral mucosal disorders in the children based on both clinical studies and those reported from biopsy records.

Materials and Methods: A literature search was completed from $1^{\text {st }}$ January 1990 to $31^{\text {st }}$ December 2018 using Pubmed and Embase.

Results: Twenty clinical studies (sample size: 85,972 ) and 34 studies from biopsy services $(40,522$ biopsies) were included. Clinically, the most frequent conditions were aphthous ulcers (1.82\%), trauma associated lesions (1.33\%) and Herpes Simplex Virus (HSV) associated lesions (1.33\%). Overall, the most commonly biopsied lesions were mucoceles (17.12\%), fibrous lesions $(9.06 \%)$ and pyogenic granuloma (4.87\%). By WHO geographical region, the pooled relative frequencies of the most common oral lesions were similar between regions in both clinical and biopsy studies. Across regions, geographic tongue (migratory glossitis), HSV lesions, fissured tongue, and traumaassociated ulcers were the most commonly reported paediatric oral mucosal lesions in clinical studies; while mucoceles, fibrous lesions and pyogenic granuloma were the most commonly biopsied lesions.

Conclusions: The scoping review suggests data from the clinical studies and biopsy records shared similarities in the most commonly observed mucosal lesions in children across regions. In addition, the majority of lesions were benign in nature.

KEYWORDS: Mouth diseases, oral manifestations, frequency, child, oral pathology

RUNNING TITLE: Relative Frequencies of Oral Lesions in Children.

WORD COUNT: 3627

NUMBER OF FIGURES: 1

NUMBER OF TABLES: 4

CONFLICT OF INTEREST: The authors declare no conflict of interest. 


\section{INTRODUCTION}

Paediatric dentistry is an age-defined specialty providing comprehensive preventive and therapeutic oral health care for infants and children through adolescence, including those with special healthcare needs (Dental Board of Australia, 2016, Commission on Dental Accreditation, 2000, Specialty Advisory Committee for Paediatric Dentistry, 2009). Pediatric dentists possess breadth of knowledge across various dental disciplines adapted to the unique requirements of children and adolescents. In childhood, dental caries is the most common chronic childhood disease (Dye et al., 2015, Chen et al., 2018, Duangthip et al., 2017), however the literature suggests oral mucosal lesions are not uncommon (Colaci \& Sfasciotti, 2013, Rioboo-Crespo Mdel et al., 2005, Furlanetto et al., 2006). Fortunately, most lesions are benign or transient; with either an infectious or traumatic aetiology. Rarely, mucosal lesions represent an oral manifestation of systemic diseases (for example, human immunodeficiency virus (HIV) infection), or adverse effects and toxicity from medical therapies (for example, oral mucositis following anti-neoplastic chemotherapy).

The literature details the majority of review papers are largely narrative in nature with the exception of two studies which attempt to quantify the prevalence of oral mucosal disorders in children (Colaci \& Sfasciotti, 2013, Furlanetto et al., 2006). Colaci et al included 12 studies published between 1988 and 2013 in their review and found wide variations in the reported prevalence of oral mucosal lesions ranging from 4.1 to $69.5 \%$ (Colaci \& Sfasciotti, 2013). Despite the variance in overall prevalence, aphthous stomatitis, herpes labialis, geographic, coated and fissured tongue, candidiasis and traumatic lesions were found to be the most frequently observed lesions in children (Colaci \& Sfasciotti, 2013). Their findings were supported by Furlanetto et al who had similar conclusions (Furlanetto et al., 2006). Unfortunately, the reviews either had unclear methodology (unclear inclusion and exclusion criteria) or focused on specific lesion types making it difficult to ascertain the true prevalence of oral lesions in children compared to adults. It is therefore difficult to define the true prevalence of pediatric mucosal lesions because of methodology issues in both the original studies and reviews.

This publication details a scoping review on the global and regional relative frequencies of oral mucosal disorders in the children based on clinical studies and those reported from biopsy services. Although rare, the early detection, diagnosis and treatment of malignant oral lesions significantly enhanced survival rates. Therefore, a secondary aim was to conduct a scoping review on potentially malignant and malignant oral lesions reported in the children. 


\section{MATERIALS AND METHODS}

A literature search was completed from $1^{\text {st }}$ January 1990 to $31^{\text {st }}$ December 2018 using Pubmed and Embase. Manuscripts selected for review were limited to the English language and based on the following inclusion and exclusion criteria. Clinical studies and biopsy reports on oral mucosal lesions and focussed studies on potentially malignant and malignant lesions in children and adolescents aged 20 or below were included. Systematic or narrative reviews, opinion papers, case reports, abstracts, animal model, in-vitro studies, studies whereby data of sample of interest could not be extracted, and papers without access (even after authors were contacted by e-mail) were excluded. In addition, HIV related oral manifestations, medical therapy induced oral manifestations and periodontitis as a manifestation of systemic diseases were excluded. The plain text or MESH (if applicable) terms used for the PubMed search are as follows: "Candidiasis, Oral", "Leukoedema, Oral", "Lichen Planus, Oral", "Lip Diseases", "Mouth Diseases", "Mouth Mucosa", "Mouth Neoplasms", "Mucositis", "Oral Manifestations", "Oral Ulcer", "Periodontal Diseases", "Salivary Gland Disorders", "Stomatitis", "Tongue Diseases", "Pathology, Oral", "Pediatric Dentistry", "Surgery, Oral" were crossed with ("AND") "Biopsy", "Prevalence", "Incidence" and "Epidemiology". The search strategy was adapted for the Embase search using the expertise of a health sciences librarian. All references were managed by reference manager software (Endnote) and duplicate papers were removed. Data was extracted using a standard electronic form. Only data on soft tissue lesions is detailed in this manuscript.

The titles and abstracts of all identified studies from the electronic search were independently assessed by the reviewers $(\mathrm{CH}, \mathrm{CN}, \mathrm{DD}, \mathrm{KH}, \mathrm{SG})$ for eligibility. Full text of studies that appeared to meet the inclusion criteria were evaluated using a piloted data collection form. Disagreements concerning the eligibility of studies were resolved by discussion with group consultants.

\section{Statistical analysis}

Quantitative analysis was carried out only for clinical and biopsy studies on oral mucosal lesions. These studies were categorized into data either from clinical studies or from biopsy records. The outcome measures used were pooled and overall relative frequency or percentage of oral lesions for clinical and biopsy studies respectively.

Relevant data were extracted from included studies for analysis of pooled relative frequency/ percentage estimates. Statistical heterogeneity was assessed using $\mathrm{I}^{2}$ statistics and chisquare test. Considering variation in true differences across sample (clinical heterogeneity and 


\section{i. Data from Clinical Studies}

There were 20 studies included in the data analysis for a total sample size of 85,976 (Basalamah \& Baroudi, 2016, Kose et al., 2013, Majorana et al., 2010, Amadori et al., 2017, Mumcu et al., 2005, Unur et al., 2015, Garcia-Pola et al., 2002, Vučićević Boras et al., 2013, Kleinman et al., 1994, Pessoa et al., 2015, Shulman, 2005, Bessa et al., 2004, dos Santos et al., 2004, Mathew et al., 2008, Vieira-Andrade et al., 2015, Arendorf \& van der Ross, 1996, Parlak et al., 2006, Vieira-Andrade et al., 2013, M, 2016, Yilmaz et al., 2011). Overall, the most prevalent conditions were aphthous ulcerations (1.82\%), trauma-associated lesions (1.33\%) and Herpes Simplex Virus (HSV) associated lesions (1.33\%). Table 1 illustrates the top 20 conditions (overall and pooled percentages) identified in these studies.

The most prevalent potentially malignant lesions were tobacco-induced lesions $(0.33 \%)$, leukoplakia (0.01\%) and oral lichen planus (0.003\%).

Stratifying by World Health Organization (WHO) geographic regions, 9 studies were from the European region, 8 from the Region of the Americas and 1 each from the African, South-East Asia and the Eastern Mediterranean regions respectively. The pooled relative frequency (random effect) of oral conditions by WHO region is presented in Table 2. Pooled relative frequency of the most common oral lesion varied between WHO regions, however, several conditions consistently 
appeared in the top ten: Ulcers (4 regions), geographic tongue (migratory glossitis) (4 regions), HSV lesions ( 3 regions), fissured tongue (3 regions), and trauma-associated lesions ( 3 regions).

Three studies (Flinck et al., 1994, George et al., 2008, Cetinkaya et al., 2011) were separately analysed as they examined conditions only in new-borns ranging from 0 to 1 week old. Of a total sample of 4080 , the 3 most prevalent conditions were mucosal cysts (36.57\%) followed by Bohn's nodules (12.06\%) and Epstein Pearls (8.95\%)

\section{ii. Data from Biopsy Records}

The review analysed data from 34 studies for a total of 40,522 biopsies performed (Lawoyin, 2000, Munsamy et al., 2011, Jaafari Ashkavandi et al., 2014, Abdullah et al., 2016, Seyedmajidi et al., 2011, Sixto-Requeijo et al., 2012, Sklavounou-Andrikopoulou et al., 2005, Gultelkin et al., 2003, Jones \& Franklin, 2006, Keszler et al., 1990, Kwok et al., 2015, Lima Gda et al., 2008, Maia et al., 2000, Martins-Filho et al., 2015, Melo, 2011, Bataineh \& Al-Dwairi, 2005, Shah et al., 2009, Sousa et al., 2002, Colaci \& Sfasciotti, 2013, Ataide et al., 2016, Cavalcante et al., 2016, Das \& Das, 1993, Zuniga et al., 2013, Krishnan et al., 2014, Lapthanasupkul et al., 2015, Dhanuthai et al., 2007, F, 2014, Wang et al., 2009, Chen et al., 1998, Ha et al., 2014, Mieko, 2007, Chidzonga et al., 1996, Maaita, 2000, Taweevisit et al., 2018). Overall, the most common biopsied lesions were mucoceles (17.12\%), fibrous lesions (9.06\%) and pyogenic granulomas (4.87\%). The top 20 oral conditions (overall and pooled percentages) are presented in Table 3.

Burkitt's lymphoma $(0.26 \%)$, non-Hodgkin's lymphoma $(0.12 \%)$, adenoid cystic carcinoma $(0.10 \%)$ and rhabdomyosarcoma $(0.10 \%)$ were the most prevalent malignancies in children based on biopsy studies.

Stratifying by World Health Organization (WHO) geographic regions, 13 studies were from the Region of Americas, 5 each from the Western Pacific and Eastern Mediterranean regions, 4 each from the European and South-East Asia regions, and 3 from the African region. The pooled percentages (random effect) of oral conditions from each WHO region are presented in Table 4. As with the data from the clinical studies, the most common biopsied lesion varied between WHO regions. The most common lesions consistently reported were mucoceles (all regions), fibrous lesions all regions) and pyogenic granulomas (5 regions).

\section{B. Focused Studies on Malignant Lesions}

Sixty-two papers, reporting exclusively on malignant lesions in children and adolescents were identified. Forty-eight papers were excluded. The main reasons for exclusion were the inability 
to extract data $(\mathrm{N}=23)$ or that the age range was outside of the interest group $(\mathrm{N}=13)$. Other reasons included non-oral or unclear cancer diagnosis terminology $(\mathrm{N}=9)$ or the full text was unavailable or not retrievable $(\mathrm{N}=3)$. Fourteen studies were retained and all were based on biopsy data (Arotiba, 1996, Budhy et al., 2001, Adebayo et al., 2001, Al-Khateeb et al., 2003, Aregbesola et al., 2005, Creath et al., 1991, latrou et al., 2013, Mohtasham et al., 2015, Piloni et al., 2009, Abiose et al., 1991, Effiom et al., 2008, Sato et al., 1997, Trobs et al., 2003, de Arruda et al., 2017). Stratifying by WHO geographic regions, 5 studies were from the African region (Arotiba, 1996, Adebayo et al., 2001, Aregbesola et al., 2005, Abiose et al., 1991, Effiom et al., 2008), 3 from the Americas (Creath et al., 1991, de Arruda et al., 2017, Piloni et al., 2009), 2 each from the Eastern Mediterranean (Al-Khateeb et al., 2003, Mohtasham et al., 2015) European (latrou et al., 2013, Trobs et al., 2003), and South East Asia/Western Pacific regions (Budhy et al., 2001, Sato et al., 1997).

In the African region, the most consistently reported oral soft tissue malignancy in children and adolescents appear to be rhabdomyosarcoma from 4 studies (Abiose et al., 1991, Arotiba, 1996, Adebayo et al., 2001, Aregbesola et al., 2005). The last study was a Nigerian study that specifically evaluated 233 cases of oral squamous cell carcinoma (SCC) over a 15-year period to characterise its behaviour. They found 19 cases of oral SCCs in children aged 0 to 19 years of age (Effiom et al., 2008). In this subset, oral SCCs was more common in males $(\mathrm{N}=15)$ and majority of the SCCs were poorly differentiated ( $N=9$ ) (Effiom et al., 2008).

In the Americas region, Piloni et al reported 24 malignant lesions of 2434 biopsied lesions in Argentinian children and adolescents between 1990-2005 (Piloni et al., 2009). Of these, 9 were located in soft tissue; leiomyosarcoma ( $N=2$, location: cheek), rhabdomyosarcoma ( $N=1$, location: lip), malignant fibrohistiocytoma: ( $N=1$; location: cheek); non-hodgkin lymphoma $(N=2$, location: sulcus), and SCC ( $N=1$, location: tongue) (Piloni et al., 2009). The other study by de Arruda et al. found 58 malignant conditions out of 9,411 histopathological records in individuals aged 0-19 years old (de Arruda et al., 2017). Excluding hard tissue malignancies, 6 were SCC (location: tongue), 3 were mucoepidermoid carcinoma (location: jugal mucosa), 2 were leiomyosarcoma (location: cheek) and 1 each of rhabdomyosarcoma (location: jugal mucosa) and adenocarcinoma (location: lip) (de Arruda et al., 2017). The study by Creath at al was not comparable to the above studies as this study focused exclusively on oral leukoplakia in a sample where smokeless tobacco use was high (Creath et al., 1991).

In the Eastern Mediterranean study by Mohtasham et al, the authors described the characteristics of non-SCC malignant oral neoplasms over a 43-year period (Mohtasham et al., 2015). Lymphomas $(\mathrm{N}=13)$ were the most prevalent malignant condition in children aged 0-19 years of age (Mohtasham et al., 2015). Unfortunately, the study did not detail the location of the lymphomas 
thus it was unclear whether these were hard or soft tissue lesions. However, the study did clearly stipulate the occurrence of other malignant oral lesions presenting on soft tissue. There was a single case of undifferentiated sarcoma, fibrosarcoma, leiomyosarcoma and rhabdomyosarcoma each (Mohtasham et al., 2015). In the other Eastern Mediterranean study by Al-Khateeb et al found 26 malignant lesions (out of 258) in North Jordanian children over a 10-year period (Al-Khateeb et al., 2003). The most common malignant lesions were extra-nodal non-hodgkin's lymphoma ( $N=6)$ and rhabdomyosarcoma $(\mathrm{N}=6)$. Although the location was specified in the study, the description given was vague and thus making it difficult to definitively ascertain whether the lesions occurred intraorally or extraorally (Al-Khateeb et al., 2003).

In Europe, a German study found 12 (13\%) malignant oral lesions in children and adolescents aged 0 to 16 years of age presenting to their institution between 1970 and 1999 . Of these, 5 (rhabdomyosarcoma: $\mathrm{N}=2$, fibrosarcoma: $\mathrm{N}=2$, metastasis of neuroblastoma: $\mathrm{N}=1$ ) presented either in the cheek or lips (Trobs et al., 2003). latrou et al reported on orofacial tumours and tumour like lesions in 211 Greek children aged between $<1$ and 15 years of age over an 11-year period and found rhabdomyosarcoma $(\mathrm{N}=6)$ to be the most common malignant lesion. Majority of these were in hard tissue and only 1 presented in soft tissue (i.e. cheek) (latrou et al., 2013).

In the South East Asia/Western Pacific regions, a study from Indonesia found SCC to be the most common malignancy in children aged 0 to 19 years of age (Budhy et al., 2001). The study did not specify the anatomic location of the lesions. This contrasted with the other Asian study in Japan which reported that sarcoma was the most common ( $n=14$ out of 18 ) malignant oral tumours in their population (Sato et al., 1997). Majority of these lesions occurred in hard tissue and only 3 were in soft tissue (i.e. buccal mucosa) (Sato et al., 1997).

\section{DISCUSSION}

In many countries, paediatric dentists or general dentists are children's initial point of contact for oral symptoms and therefore will frequently be the first to notice an oral mucosal lesion. However, the broad scope and fast pace of Paediatric Dentistry may limit the provider's experience with rarer oral mucosal disorders. To our knowledge, this review represents the first attempt to quantify the global and region-specific relative frequency of oral mucosal disorders in the paediatric sample. This study also systematically examined both clinical and histopathologic studies allowing for a more complete description of the spectrum of mucosal disorders in children than previously reported. Information on the relative lesion frequency from this review may serve as a guide for deriving differential diagnosis for oral lesions encountered in children. 
In general, data from the clinical studies revealed similarities in the most commonly observed mucosal lesions in children across regions. They were trauma associated lesions $(2.5 \%$ $4.1 \%)$, fissured tongue $(0.3-4.0 \%)$, oral ulcers $(0.3-4.8 \%)$ and migratory glossitis $(0.1-2.8 \%)$. An exception was the study by Arendorf et al., who found that angular cheilitis (15.1\%) and commissural lip pits (9.6\%) were the two most common oral mucosal lesions in South African preschool children (15.1\%) which differed from other regions (Arendorf \& van der Ross, 1996). Authors attributed the high frequency of angular cheilitis and commissural lip pits to be secondary to nutritional deficiencies and ethnicity predilection (Arendorf \& van der Ross, 1996). Another possibility is the exclusion of commissural lip pits in the reporting of oral pathology in other studies.

In new-borns, mucosal cysts, Bohn's nodules and Epstein pearls were the top 3 most common lesions (Flinck et al., 1994, Cetinkaya et al., 2011, George et al., 2008). This finding is aligned with current knowledge from textbooks and reports from the literature (Neville BW, 2015). Although there were other studies that included new-borns in their sample, the specific data for this age group could not be extracted.

As with the data from the clinical studies, most of the lesions reported from biopsy samples were similar across regions; with pyogenic granuloma (2.4-20.3\%), fibrous lesions $(4.2-20.2 \%)$ and mucocele (5.8 - 20.0\%) being the most common.

The qualitative review on malignant lesions found that variations in study design made the comparison of the results between studies difficult or impossible even in those originating from the same geographic region. However, it was clear that overall oral soft tissue malignancies were rare in children. Rhabdomyosarcomas appeared to be the most common oral soft tissue malignancy in majority of the geographic regions. Of note, the study by Budhy et al deviated from this trend and oral SCCs was reported to be most common malignancy in children (Budhy et al., 2001). The authors proposed that the low social economic status and poor nutritional status of the East Javan population may have contributed to this finding but this was not specific to children. The finding that Rhabdomyosarcoma being the most common oral soft tissue malignancy was also not align with the quantitative data from the biopsy review. This is likely due to the exclusion of malignant conditions presenting in hard tissue during the qualitative review on oral soft tissue malignancies.

A significant limitation of undertaking this review was the varying definitions across reports of what was considered "paediatric". For this review, age 20 years was chosen as the upper limit of what was considered "paediatric" as the blanket exclusion of all groups with older age thresholds would have inappropriately eliminated data addressing our research objective. Given the physiologic, developmental, and social differences between early childhood and adolescence, it would have been worthwhile to analyse the data by ages. However, varying maximum age of what 
was considered "paediatric", the arbitrary classification of lesions by age (e.g., 0-10 years old versus 11-20 years old) and the inability to extract raw data by age made this impossible.

Similar to other groups, our review noted several inherent limitations when combining and interpreting data from studies with different study designs. We found significant differences in the studies relative to study samples, diagnostic criteria, lesion nomenclature, and sampling time frame. Although majority of clinical studies used the WHO guide to epidemiology and diagnosis of oral mucosal diseases (Kramer et al., 1980), wide variations in lesion nomenclature across studies was still present. The general observation was the failure of the studies to use the exact terminology stipulated by the guide. As such, there was a need to make some assumptions regarding lesion terminology. Initial data abstraction recorded the exact terminology from each included study. These terms were then reviewed by 2 of the authors and combined for data analysis. In the majority of the cases, the decision to combine terms was straightforward (recurrent aphthous stomatitis and aphthous ulcerations). In instances where it was unclear, the term was left unchanged or grouped based on aetiology (e.g. HSV associated lesion rather than primary or recurrent HSV) to avoid misinterpretation of the data presented in the primary source.

Despite the limitations, a scoping review on the relative frequencies of oral lesions in children is the first step towards defining paediatric oral medicine. The management of all oral mucosal lesions does not clearly fall within the scope of Paediatric Dentistry and patients may be referred to either Oral Medicine or other (e.g., Oral Pathology, Oral Surgery, Periodontology) specialties for evaluation and treatment. Oral Medicine specialists are dentists that are concerned with the diagnosis and management of oral and medical conditions that affect the oral and maxillofacial region, but often lack experience working with children. The question then lies as to whom and how should these two oral specialties collaborate to manage oral lesions affecting the children. To address this, collaboration between Oral Medicine and Paediatric Dentistry is essential to ensure that children affected with common oral conditions are promptly diagnosed and managed within Paediatric Dentistry; while those afflicted with rarer and potentially more severe disorders are quickly referred to the appropriate specialists for management. Joint Paediatric Dentistry/Oral Medicine clinics specific for the diagnosis and management of oral mucosal lesions in children, while ideal, are uncommon and only available in select institutions. Thus, a good starting point may be to utilize information from this report to refine the curricula in Paediatric Dentistry and Oral Medicine specialty training programmes to reflect lesion epidemiology and the global burden of disease. Emphasis can be placed on the identification, diagnosis, and management of lesions most commonly encountered in practice and also on rare life-threatening diseases with significant potential impact on a patient's quality of life. Our next steps are to elicit input from educators of Paediatric Dentistry 
specialty programmes on current oral medicine curricula and the considerations made when determining the scope of oral medicine content in their paediatric programmes. Additionally, a focused survey of paediatric dentists and oral medicine specialists who deliver "joint" clinics aim to elicit whether conditions managed in this clinical setting mirrors the results reported here. We hope information from both initiatives will provide another element to better define the paediatric oral medicine and direct delineation of practice of oral medicine in children across paediatric dentists and oral medicine specialists.

\section{ACKNOWLEDGEMENTS}

The authors gratefully acknowledge the following organizations and companies that provided financial support for WWOM VII: American Academy of Oral Medicine, European Association of Oral Medicine, The British Society for Oral Medicine, The National Institute of Dental and Craniofacial Research, Oral Diseases, Henry Schein Cares, Colgate, Xerostomia, Dermtreat, The World Dental Education Foundation, and Unilever.

In addition, the authors would like to express their sincere appreciation for the opportunity to collaborate with the WWOM VII Steering Committee. This committee provided the conceptual framework and logistical support to produce the WWOM VII Conference in September 2018 in Gothenburg, Sweden. In addition, the Steering Committee provided scientific and editorial critiques of this manuscript. The entire Steering Committee is listed below, in alphabetical order: Martin S. Greenberg (USA), Timothy A. Hodgson (UK), Siri Beier Jensen (Denmark), A. Ross Kerr (USA), Peter B. Lockhart (USA), Giovanni Lodi (Italy), Douglas E. Peterson (USA).

Lastly, the authors would like to thank our consultants Sabine Jurge and Andres Pinto, who provided valuable suggestions to authors. 


\section{REFERENCES}

Abdullah BH, Jabbar Abdul Qader OA and Mussedi OS (2016). Retrospective analysis of 1286 oral and maxillofacial biopsied lesions of Iraqi children over a 30 years period. Pediatric Dental Journal 26: 1620.

Abiose BO, Ogunniyi J and Oyejide O (1991). Oral soft tissue malignancies in Ibadan, Nigeria. African journal of medicine and medical sciences 20: 107-13.

Adebayo ET, Ajike SO and Adekeye EO (2001). Tumours and tumour-like lesions of the oral and perioral structures of Nigerian children. International journal of oral and maxillofacial surgery $\mathbf{3 0}$ 205-8.

Al-Khateeb T, Al-Hadi Hamasha A and Almasri NM (2003). Oral and maxillofacial tumours in north Jordanian children and adolescents: a retrospective analysis over 10 years. International journal of oral and maxillofacial surgery 32: 78-83.

Amadori F, Bardellini E, Conti G and Majorana A (2017). Oral mucosal lesions in teenagers: a crosssectional study. Ital J Pediatr 43: 50.

Aregbesola SB, Ugboko VI, Akinwande JA, Arole GF and Fagade OO (2005). Orofacial tumours in suburban Nigerian children and adolescents. The British journal of oral \& maxillofacial surgery 43: 226-31.

Arendorf TM and van der Ross R (1996). Oral soft tissue lesions in a black pre-school South African population. Community dentistry and oral epidemiology 24: 296-7.

Arotiba GT (1996). A study of orofacial tumors in Nigerian children. Journal of oral and maxillofacial surgery : official journal of the American Association of Oral and Maxillofacial Surgeons 54: 34-8; discussion 39.

Ataide AP, Fonseca FP, Santos Silva AR, Jorge Junior J, Lopes MA and Vargas PA (2016). Distribution of oral and maxillofacial lesions in pediatric patients from a Brazilian southeastern population. International journal of pediatric otorhinolaryngology 90: 241-244.

Basalamah M and Baroudi K (2016). Prevalence of oro-dental anomalies among schoolchildren in Sana'a city, Yemen. Eastern Mediterranean health journal = La revue de sante de la Mediterranee orientale = al-Majallah al-sihhiyah li-sharq al-mutawassit 22: 33-8.

Bataineh A and AI-Dwairi ZN (2005). A survey of localized lesions of oral tissues: a clinicopathological study. The journal of contemporary dental practice 6: 30-9.

Bessa CF, Santos PJ, Aguiar MC and do Carmo MA (2004). Prevalence of oral mucosal alterations in children from 0 to 12 years old. Journal of oral pathology \& medicine : official publication of the 
International Association of Oral Pathologists and the American Academy of Oral Pathology 33: 1722.

Budhy TI, Soenarto SD, Yaacob HB and Ngeow WC (2001). Changing incidence of oral and maxillofacial tumours in East Java, Indonesia, 1987-1992. Part 2: Malignant tumours. The British journal of oral \& maxillofacial surgery 39: 460-4.

Cavalcante RB, Turatti E, Daniel AP, de Alencar GF and Chen Z (2016). Retrospective review of oral and maxillofacial pathology in a Brazilian paediatric population. Eur Arch Paediatr Dent 17: 115-22. Cetinkaya M, Oz FT, Orhan AI, Orhan K, Karabulut B, Can-Karabulut DC and Ilk O (2011). Prevalence of oral abnormalities in a Turkish newborn population. International dental journal 61: 90-100. Chen KJ, Gao SS, Duangthip D, Lo ECM and Chu CH (2018). Prevalence of early childhood caries among 5-year-old children: A systematic review. J Investig Clin Dent: e12376.

Chen YK, Lin LM, Huang HC, Lin CC and Yan YH (1998). A retrospective study of oral and maxillofacial biopsy lesions in a pediatric population from southern Taiwan. Pediatric dentistry 20: 404-10. Chidzonga MM, Lopez VM and Portilla Alvarez AL (1996). Orofacial biopsies: a survey of 1,723 cases seen over a 10 year period. The Central African journal of medicine 42: 102-8.

Colaci R and Sfasciotti G (2013). Most common oral mucosal lesions in children: Prevalence and differential diagnosis. WedmedCentral DENTISTRY 4.

Commission on Dental Accreditation (2000). Accreditation Standards for Advanced Specialty Education Programs in Pediatric Dentistry.

Creath CJ, Cutter G, Bradley DH and Wright JT (1991). Oral leukoplakia and adolescent smokeless tobacco use. Oral surgery, oral medicine, and oral pathology 72: 35-41.

Das $S$ and Das AK (1993). A review of pediatric oral biopsies from a surgical pathology service in a dental school. Pediatric dentistry 15: 208-11.

de Arruda JAA, Silva LVO, Kato C, Schuch LF, Batista AC, Costa NL, Tarquinio SBC, Rivero ERC, Carrard VC, Martins MD, Sobral APV and Mesquita RA (2017). A multicenter study of malignant oral and maxillofacial lesions in children and adolescents. Oral Oncol 75: 39-45.

Dental Board of Australia (2016). Entry-level competencies: paediatric dentistry. In: Dental Board of Australia, ed.

Dhanuthai K, Banrai M and Limpanaputtajak S (2007). A retrospective study of paediatric oral lesions from Thailand. International journal of paediatric dentistry 17: 248-53.

dos Santos PJ, Bessa CF, de Aguiar MC and do Carmo MA (2004). Cross-sectional study of oral mucosal conditions among a central Amazonian Indian community, Brazil. Journal of oral pathology \& medicine : official publication of the International Association of Oral Pathologists and the American Academy of Oral Pathology 33: 7-12. 
Duangthip D, Gao SS, Lo EC and Chu CH (2017). Early childhood caries among 5- to 6-year-old children in Southeast Asia. International dental journal 67: 98-106.

Dye BA, Hsu KL and Afful J (2015). Prevalence and Measurement of Dental Caries in Young Children. Pediatric dentistry 37: 200-16.

Effiom OA, Adeyemo WL, Omitola OG, Ajayi OF, Emmanuel MM and Gbotolorun OM (2008). Oral squamous cell carcinoma: a clinicopathologic review of 233 cases in Lagos, Nigeria. Journal of oral and maxillofacial surgery : official journal of the American Association of Oral and Maxillofacial Surgeons 66: 1595-9.

F L (2014). Retrospective study of biopsied oral and maxillofacial lesions in pediatric patients from Southern Taiwan. Journal of Dental Sciences 9.

Flinck A, Paludan A, Matsson L, Holm AK and Axelsson I (1994). Oral findings in a group of newborn Swedish children. International journal of paediatric dentistry 4: 67-73.

Furlanetto DL, Crighton A and Topping GV (2006). Differences in methodologies of measuring the prevalence of oral mucosal lesions in children and adolescents. International journal of paediatric dentistry 16: 31-9.

Garcia-Pola MJ, Garcia-Martin JM and Gonzalez-Garcia M (2002). Prevalence of oral lesions in the 6year-old pediatric population of Oviedo (Spain). Medicina oral : organo oficial de la Sociedad Espanola de Medicina Oral y de la Academia Iberoamericana de Patologia y Medicina Bucal 7: 18491.

George D, Bhat SS and Hegde SK (2008). Oral findings in newborn children in and around Mangalore, Karnataka State, India. Medical principles and practice : international journal of the Kuwait University, Health Science Centre 17: 385-9.

Gultelkin SE, Tokman B and Turkseven MR (2003). A review of paediatric oral biopsies in Turkey. International dental journal 53: 26-32.

Ha WN, Kelloway E, Dost F and Farah CS (2014). A retrospective analysis of oral and maxillofacial pathology in an Australian paediatric population. Australian dental journal 59: 221-5.

latrou I, Theologie-Lygidakis N, Tzerbos F and Schoinohoriti OK (2013). Oro-facial tumours and tumour-like lesions in Greek children and adolescents: an 11-year retrospective study. Journal of cranio-maxillo-facial surgery : official publication of the European Association for Cranio-MaxilloFacial Surgery 41: 437-43.

Jaafari Ashkavandi Z, Ahmadi Sheshdeh Z and Kamali F (2014). Orofacial pathologic lesions in children and adolescents: a clinicopathological study in southern iran. Iran J Pediatr 24: 307-12. Jones AV and Franklin CD (2006). An analysis of oral and maxillofacial pathology found in children over a 30-year period. International journal of paediatric dentistry 16: 19-30. 
Keszler A, Guglielmotti MB and Dominguez FV (1990). Oral pathology in children. Frequency, distribution and clinical significance. Acta odontologica latinoamericana : AOL 5: 39-48.

Kleinman DV, Swango PA and Pindborg JJ (1994). Epidemiology of oral mucosal lesions in United States schoolchildren: 1986-87. Community dentistry and oral epidemiology 22: 243-53. Kose O, Guven G, Ozmen I, Akgun OM and Altun C (2013). The oral mucosal lesions in pre-school and school age Turkish children. Journal of the European Academy of Dermatology and Venereology : JEADV 27: e136-7.

Kramer IR, Pindborg JJ, Bezroukov V and Infirri JS (1980). Guide to epidemiology and diagnosis of oral mucosal diseases and conditions. World Health Organization. Community dentistry and oral epidemiology 8: 1-26.

Krishnan R, Ramesh M and Paul G (2014). Retrospective evaluation of pediatric oral biopsies from a dental and maxillofacial surgery centre in salem, Tamil Nadu, India. J Clin Diagn Res 8: 221-3. Kwok EY, Dovigi EA, Eversole LR and Dovigi AJ (2015). Pediatric Oral Pathology: A Retrospective Survey of 4,554 Biopsies. Pediatric dentistry 37: 546-9.

Lapthanasupkul P, Juengsomjit R, Klanrit P, Taweechaisupapong S and Poomsawat S (2015). Oral and maxillofacial lesions in a Thai pediatric population: a retrospective review from two dental schools. Journal of the Medical Association of Thailand = Chotmaihet thangphaet 98: 291-7. Lawoyin JO (2000). Paediatric oral surgical pathology service in an African population group: a 10 year review. Odonto-stomatologie tropicale = Tropical dental journal 23: 27-30. Lima Gda S, Fontes ST, de Araujo LM, Etges A, Tarquinio SB and Gomes AP (2008). A survey of oral and maxillofacial biopsies in children: a single-center retrospective study of 20 years in PelotasBrazil. Journal of applied oral science : revista FOB 16: 397-402. M Y (2016). Prevalence of Oral Mucosal Lesions In Children. Int J Odontostomat. Maaita JK (2000). Oral tumors in children: a review. The Journal of clinical pediatric dentistry 24: 1335.

Maia DM, Merly F, Castro WH and Gomez RS (2000). A survey of oral biopsies in Brazilian pediatric patients. ASDC journal of dentistry for children 67: 128-31, 83.

Majorana A, Bardellini E, Flocchini P, Amadori F, Conti G and Campus G (2010). Oral mucosal lesions in children from 0 to 12 years old: ten years' experience. Oral surgery, oral medicine, oral pathology, oral radiology, and endodontics 110: e13-8.

Martins-Filho PR, de Santana Santos T, Piva MR, da Silva HF, da Silva LC, Mascarenhas-Oliveira AC and de Souza Andrade ES (2015). A Multicenter Retrospective Cohort Study on Pediatric Oral Lesions. J Dent Child (Chic) 82: 84-90. 
Mathew AL, Pai KM, Sholapurkar AA and Vengal M (2008). The prevalence of oral mucosal lesions in patients visiting a dental school in Southern India. Indian journal of dental research : official publication of Indian Society for Dental Research 19: 99-103.

Melo MMM (2011). Oral and maxillofacial biopsied lesions in Brazilian pediatric patients: A 16-year retrospective study. Rev Odonto Cienc 26.

Mieko T (2007). Oral conditions in Japanese Infants: A retrospective study. Pediatric Dental Journal 17.

Mohtasham N, Saghravanian N, Goli M and Kadeh H (2015). Oral Non Squamous Cell Malignant Tumors in an Iranian Population: a 43 year Evaluation. Asian Pacific journal of cancer prevention : APJCP 16: 8215-20.

Mumcu G, Cimilli H, Sur H, Hayran O and Atalay T (2005). Prevalence and distribution of oral lesions: a cross-sectional study in Turkey. Oral diseases 11: 81-7.

Munsamy C, Mahomed F and Rikhotso E (2011). A 20-year retrospective study of oral and maxillofacial histopathology in a South African paediatric population sample. SADJ : journal of the South African Dental Association = tydskrif van die Suid-Afrikaanse Tandheelkundige Vereniging 66: 268-71.

Neville BW DD, Allen CM, Chi AC (2015). Oral and Maxillofacial Pathology. Chapter 1. Developmental Defects of the Oral and Maxillofacial Region. 6th Edition. Saunders, p. 928.

Parlak AH, Koybasi S, Yavuz T, Yesildal N, Anul H, Aydogan I, Cetinkaya R and Kavak A (2006). Prevalence of oral lesions in 13- to 16-year-old students in Duzce, Turkey. Oral diseases 12: 553-8. Pessoa CP, Alves TD, dos Santos NC, dos Santos HL, Azevedo Ade C, dos Santos JN and Oliveira MC (2015). Epidemiological survey of oral lesions in children and adolescents in a Brazilian population. International journal of pediatric otorhinolaryngology 79: 1865-71.

Piloni MJ, Molina G and Keszler A (2009). Malignant oral-maxillary neoplasm in children and adolescents. A retrospective analysis from the biopsy service at a school of dentistry in Argentina. Acta odontologica latinoamericana : AOL 22: 233-8.

Rioboo-Crespo Mdel R, Planells-del Pozo P and Rioboo-Garcia R (2005). Epidemiology of the most common oral mucosal diseases in children. Medicina oral, patologia oral y cirugia bucal 10: 376-87. Sato M, Tanaka N, Sato T and Amagasa T (1997). Oral and maxillofacial tumours in children: a review. The British journal of oral \& maxillofacial surgery 35: 92-5.

Seyedmajidi M, Hamzehpoor M and Bagherimoghaddam S (2011). Localized lesions of oral cavity: A clinicopathological study of 107 cases. Research Journal of Medical Sciences 5: 67-72.

Shah SK, Le MC and Carpenter WM (2009). Retrospective review of pediatric oral lesions from a dental school biopsy service. Pediatric dentistry 31: 14-9. 
Shulman JD (2005). Prevalence of oral mucosal lesions in children and youths in the USA. International journal of paediatric dentistry 15: 89-97.

Sixto-Requeijo R, Diniz-Freitas M, Torreira-Lorenzo JC, Garcia-Garcia A and Gandara-Rey JM (2012). An analysis of oral biopsies extracted from 1995 to 2009, in an oral medicine and surgery unit in Galicia (Spain). Medicina oral, patologia oral y cirugia bucal 17: e16-22.

Sklavounou-Andrikopoulou A, Piperi E, Papanikolaou V and Karakoulakis I (2005). Oral soft tissue lesions in Greek children and adolescents: a retrospective analysis over a 32-year period. The Journal of clinical pediatric dentistry 29: 175-8.

Sousa FB, Etges A, Correa L, Mesquita RA and de Araujo NS (2002). Pediatric oral lesions: a 15-year review from Sao Paulo, Brazil. The Journal of clinical pediatric dentistry 26: 413-8.

Specialty Advisory Committee for Paediatric Dentistry (2009). Specialty Training Curriculum Paediatric Dentistry. In: The Royal College of Surgeons of England, ed. SAC/CDWP: MLH2009 FINAL. Taweevisit M, Tantidolthanes W, Keelawat S and Thorner PS (2018). Paediatric oral pathology in Thailand: a 15-year retrospective review from a medical teaching hospital. International dental journal 68: 227-234.

Trobs RB, Mader E, Friedrich T and Bennek J (2003). Oral tumors and tumor-like lesions in infants and children. Pediatric surgery international 19: 639-45.

Unur M, Bektas Kayhan K, Altop MS, Boy Metin Z and Keskin Y (2015). The prevalence of oral mucosal lesions in children:a single center study. J Istanb Univ Fac Dent 49: 29-38.

Vale EB, Ramos-Perez FM, Rodrigues GL, Carvalho EJ, Castro JF and Perez DE (2013). A review of oral biopsies in children and adolescents: A clinicopathological study of a case series. J Clin Exp Dent 5: e144-9.

Vieira-Andrade RG, Martins-Junior PA, Correa-Faria P, Marques LS, Paiva SM and Ramos-Jorge ML (2015). Impact of oral mucosal conditions on oral health-related quality of life in preschool children: a hierarchical approach. International journal of paediatric dentistry 25: 117-26.

Vieira-Andrade RG, Martins-Junior PA, Correa-Faria P, Stella PE, Marinho SA, Marques LS and RamosJorge ML (2013). Oral mucosal conditions in preschool children of low socioeconomic status: prevalence and determinant factors. European journal of pediatrics 172: 675-81.

Vučićević Boras V, Andabak Rogulj A, Alajbeg I, Skrinjar I, Brzak BL, Brailo V, Vidović Juras D and Verzak Z (2013). The prevalence of oral mucosal lesions in Croatian children. Paediatria Croatica 57: 235-238.

Wang YL, Chang HH, Chang JY, Huang GF and Guo MK (2009). Retrospective survey of biopsied oral lesions in pediatric patients. Journal of the Formosan Medical Association = Taiwan yi zhi 108: 86271. 
Yilmaz AE, Gorpelioglu C, Sarifakioglu E, Dogan DG, Bilici M and Celik N (2011). Prevalence of oral mucosal lesions from birth to two years. Nigerian journal of clinical practice 14: 349-53.

Zuniga MD, Mendez CR, Kauterich RR and Paniagua DC (2013). Paediatric oral pathology in a Chilean population: a 15-year review. International journal of paediatric dentistry 23: 346-51. 


\section{Figure 1: PRISMA Diagram}

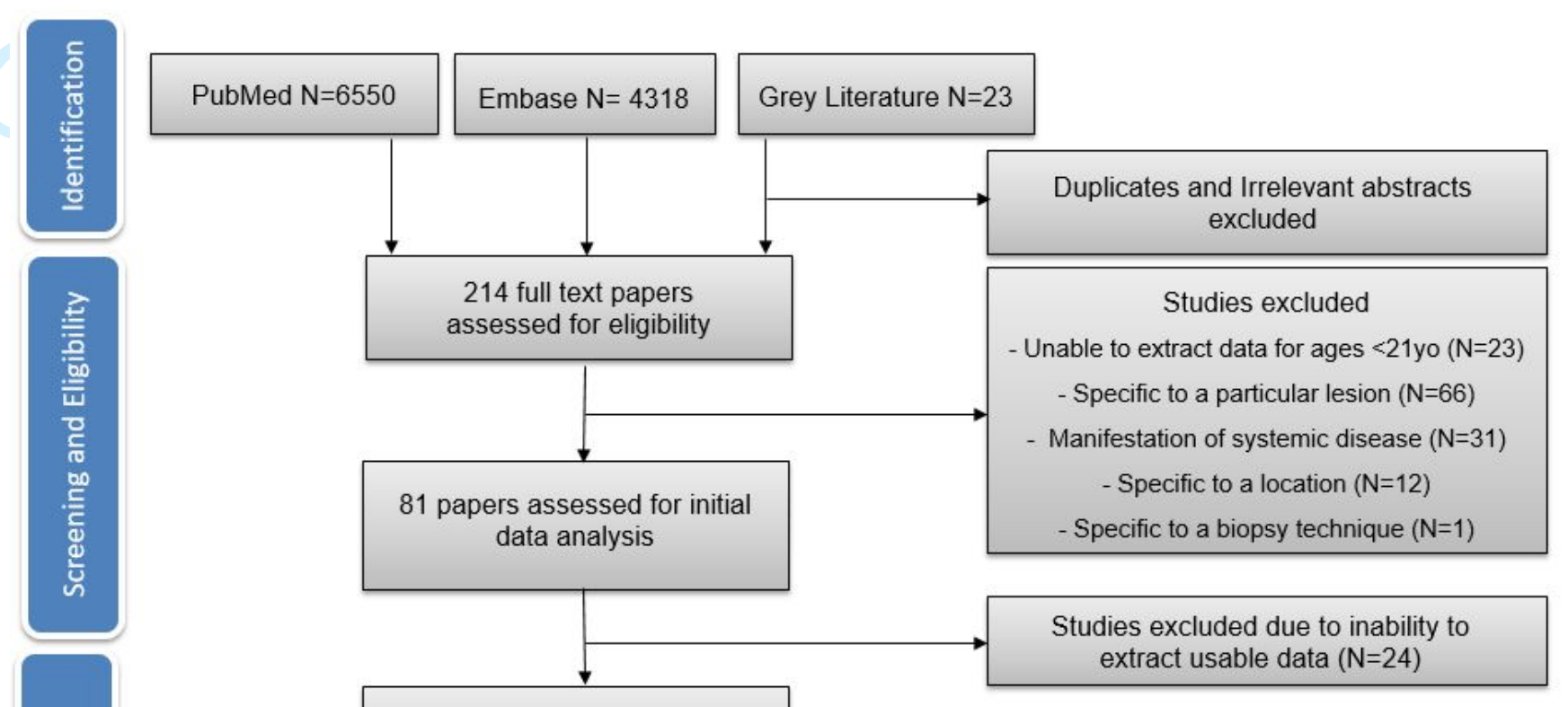

26

27

28

29

30

31

32

33

34

35 
Table 1: Top 20 most frequent (overall and pooled) oral conditions based on clinical studies

\begin{tabular}{|c|c|c|c|c|c|}
\hline Condition & $\begin{array}{c}\text { Total cases } \\
\text { (out of } \\
85976 \text { ) }\end{array}$ & $\begin{array}{c}\text { Relative } \\
\text { Frequency } \\
(\%)\end{array}$ & $\begin{array}{l}\text { Number } \\
\text { of Studies }\end{array}$ & $\begin{array}{c}\text { Pooled } \\
\text { Relative } \\
\text { Frequency } \\
\text { (\%) }\end{array}$ & 95\% Cl (\%) \\
\hline Aphthous ulcer & 1569 & 1.82 & 15 & 1.75 & $1.05-2.61$ \\
\hline HSVa lesions & 1145 & 1.33 & 13 & 1.38 & $0.79-2.13$ \\
\hline Trauma-associated lesions & 1145 & 1.33 & 10 & 3.55 & $1.99-5.55$ \\
\hline Migratory glossitis & 1106 & 1.29 & 17 & 2.08 & $1.33-2.97$ \\
\hline Candidiasis & 1029 & 1.20 & 13 & 1.34 & $0.13-3.68$ \\
\hline Ulcer & 410 & 0.48 & 8 & 2.45 & $0.50-5.76$ \\
\hline Cheilitis & 381 & 0.44 & 14 & 1.37 & $0.49-2.64$ \\
\hline Hyperkeratosis & 292 & 0.34 & 7 & 1.38 & $0.53-2.59$ \\
\hline Tobacco-induced & 274 & 0.32 & 4 & 0.21 & $0.03-0.54$ \\
\hline Melanotic macule & 273 & 0.32 & 8 & 2.92 & $0.52-7.10$ \\
\hline Hairy tongue & 237 & 0.28 & 4 & 0.70 & $0.09-1.79$ \\
\hline Fordyce granule & 212 & 0.25 & 8 & 1.91 & $0.70-3.67$ \\
\hline $\mathrm{HPV}^{\mathrm{b}}$ lesions & 185 & 0.22 & 13 & 0.59 & $0.24-1.06$ \\
\hline Mucocele & 174 & 0.20 & 12 & 0.89 & $0.35-1.65$ \\
\hline Fissured tongue & 168 & 0.20 & 13 & 0.90 & $0.36-1.66$ \\
\hline Nevi & 158 & 0.18 & 2 & 1.44 & $1.22-1.68$ \\
\hline Coated tongue & 129 & 0.15 & 1 & 23.84 & $20.31-27.67$ \\
\hline Commissural lip pits & 115 & 0.13 & 3 & 2.46 & $0.00-9.32$ \\
\hline Other (NOSc) & 108 & 0.13 & 1 & 0.25 & $0.20-0.30$ \\
\hline Tumours (NOSc) & 84 & 0.10 & 2 & 0.15 & $0.12-0.19$ \\
\hline
\end{tabular}

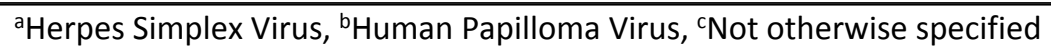


Table 2: Top 10 most frequent (pooled) oral conditions by WHO regions based on clinical studies

\begin{tabular}{|c|c|c|c|c|c|c|c|c|}
\hline \multicolumn{3}{|c|}{ African Region (Arendorf \& van der Ross, 1996) } & \multicolumn{3}{|c|}{ Eastern Mediterranean Region (Basalamah \& Baroudi, 2016) } & \multicolumn{3}{|c|}{$\begin{array}{l}\text { European Region (Kose et al., 2013, Amadori et al., 2017, } \\
\text { Mumcu et al., 2005, Unur et al., 2015, Garcia-Pola et al., } \\
\text { 2002, Vučićević Boras et al., 2013, Parlak et al., 2006, Yilmaz } \\
\text { et al., 2011, Majorana et al., 2010) }\end{array}$} \\
\hline Condition & $\begin{array}{l}\text { Pooled relative } \\
\text { frequency (\%) }\end{array}$ & $95 \% \mathrm{Cl}(\%)$ & Condition & $\begin{array}{l}\text { Pooled relative } \\
\text { frequency (\%) }\end{array}$ & $\begin{array}{l}95 \% \mathrm{Cl} \\
(\%)\end{array}$ & Condition & $\begin{array}{l}\text { Pooled relative } \\
\text { frequency (\%) }\end{array}$ & $95 \% \mathrm{Cl}(\%)$ \\
\hline Cheilitis & 15.13 & $13.01-17.44$ & Fissured tongue & 4.00 & $2.87-5.41$ & Trauma-associated lesions & 3.48 & $1.21-6.58$ \\
\hline Commissural lip pits & 9.61 & $7.90-11.55$ & Ankyloglossia & 1.80 & $1.07-2.83$ & Fistula & 3.21 & $1.97-4.91$ \\
\hline Trauma-associated lesions & 2.47 & $1.62-3.60$ & Migratory glossitis & 0.90 & $0.41-1.70$ & Ulcers & 3.20 & 2.79-3.64 \\
\hline Migratory glossitis & 1.62 & $0.95-2.58$ & Macroglossia & 0.40 & $0.11-1.02$ & Candidiasis & 2.87 & $0.55-6.85$ \\
\hline HSVa lesions & 0.95 & $0.46-1.75$ & Hairy tongue & 0.30 & $0.06-0.87$ & Hyperkeratosis & 2.78 & $2.42-3.17$ \\
\hline Pigmented lesions & 0.76 & $0.33-1.49$ & & & & Epstein pearls & 2.68 & $1.16-5.20$ \\
\hline Fissured tongue & 0.57 & $0.21-1.24$ & & & & Migratory glossitis & 2.15 & $1.20-3.35$ \\
\hline Ulcers & 0.48 & $0.15-1.11$ & & & & Aphthous ulcer & 2.09 & $0.95-3.63$ \\
\hline $\mathrm{HPV}^{\mathrm{b}}$ lesions & 0.48 & $0.15-1.11$ & & & & HSV lesions & 1.91 & $1.04-3.03$ \\
\hline Necrotizing ulcerative gingivitis & 0.19 & $0.02-0.69$ & & & & Cheilitis & 1.08 & $0.37-2.13$ \\
\hline \multicolumn{3}{|c|}{$\begin{array}{l}\text { Region of the Americas (Kleinman et al., 1994, Pessoa et al., 2015, } \\
\text { Shulman, 2005, Bessa et al., 2004, dos Santos et al., 2004, M, 2016, } \\
\text { Vieira-Andrade et al., 2015, Vieira-Andrade et al., 2013) }\end{array}$} & South-Ea & ion (Mathew et a & & \multicolumn{3}{|c|}{ Western Pacific Region (No studies) } \\
\hline Condition & $\begin{array}{l}\text { Pooled relative } \\
\text { frequency (\%) }\end{array}$ & 95\% Cl (\%) & Condition & $\begin{array}{l}\text { Pooled relative } \\
\text { frequency (\%) }\end{array}$ & $\begin{array}{l}95 \% \mathrm{Cl} \\
(\%)\end{array}$ & Condition & $\begin{array}{l}\text { Pooled relative } \\
\text { frequency (\%) }\end{array}$ & $95 \% \mathrm{Cl}(\%)$ \\
\hline Coated tongue & 23.84 & 20.31-27.67 & Fordyce granule & 0.50 & $0.19-1.09$ & & & \\
\hline Other inflammatory lesions (NOSc) & 8.61 & $5.93-12.00$ & Hyperkeratosis & 0.42 & $0.14-0.98$ & & & \\
\hline Melanotic macule & 7.35 & $1.34-17.53$ & Ulcers & 0.34 & $0.09-0.86$ & & & \\
\hline Pyogenic granuloma & 5.28 & $3.21-8.12$ & Aphthous ulcer & 0.34 & $0.09-0.86$ & & & \\
\hline Ulcers & 4.76 & $0.00-16.78$ & Fissured tongue & 0.34 & $0.09-0.86$ & & & \\
\hline Fordyce granule & 4.74 & $0.16-14.71$ & Migratory glossitis & 0.08 & $0.00-0.47$ & & & \\
\hline Trauma-associated lesions & 4.12 & $1.17-8.72$ & Mucocele & 0.08 & $0.00-0.47$ & & & \\
\hline Migratory glossitis & 2.79 & $1.32-4.77$ & HSVa $^{\text {lesions }}$ & 0.08 & $0.00-0.47$ & & & \\
\hline Peripheral ossifying fibroma & 2.50 & $1.15-4.69$ & Candidiasis & 0.08 & $0.00-0.47$ & & & \\
\hline Dermatologic disorders & 2.50 & $1.15-4.69$ & Tobacco-induced & 0.08 & $0.00-0.47$ & & & \\
\hline
\end{tabular}

aHerpes Simplex Virus, bHuman Papilloma Virus, c Not otherwise specified 
Table 3: Top 20 most frequent (overall and pooled) oral conditions based on biopsy reviews

\begin{tabular}{|c|c|c|c|c|c|}
\hline Condition & $\begin{array}{c}\text { Total cases } \\
\text { (out of } \mathbf{4 0 5 2 2} \text { ) }\end{array}$ & $\begin{array}{c}\text { Percentage } \\
\text { (\%) }\end{array}$ & $\begin{array}{c}\text { Number of } \\
\text { studies }\end{array}$ & $\begin{array}{c}\text { Pooled } \\
\text { relative } \\
\text { frequency }(\%)\end{array}$ & $95 \% \mathrm{Cl}(\%)$ \\
\hline Mucocele & 6938 & 17.12 & 27 & 16.70 & $13.27-20.43$ \\
\hline Fibrous lesions & 3671 & 9.06 & 30 & 7.36 & $5.33-9.67$ \\
\hline Pyogenic granuloma & 1975 & 4.87 & 31 & 6.38 & $4.87-8.08$ \\
\hline Dental follicle & 1462 & 3.61 & 19 & 4.93 & $3.39-6.72$ \\
\hline Human Papilloma Virus lesions & 1136 & 2.80 & 27 & 2.38 & $1.76-3.08$ \\
\hline Chronic inflammation & 998 & 2.46 & 19 & 4.55 & $3.13-6.21$ \\
\hline Giant cell lesions (soft tissue) & 971 & 2.40 & 21 & 3.75 & $2.36-5.43$ \\
\hline Hyperkeratosis & 842 & 2.08 & 9 & 3.26 & $1.06-6.57$ \\
\hline Peripheral ossifying fibroma & 509 & 1.26 & 16 & 1.89 & $1.31-2.58$ \\
\hline Gingivitis & 487 & 1.20 & 10 & 1.33 & $0.62-2.28$ \\
\hline Gingival hyperplasia & 409 & 1.01 & 10 & 2.06 & $0.76-3.94$ \\
\hline Haemangioma & 393 & 0.97 & 24 & 2.09 & $1.43-2.86$ \\
\hline Ulcer & 148 & 0.37 & 11 & 1.25 & $0.71-1.92$ \\
\hline Lymphangioma & 135 & 0.33 & 13 & 1.06 & $0.61-1.62$ \\
\hline Sialadenitis & 119 & 0.29 & 8 & 0.75 & $0.29-1.40$ \\
\hline Burkitt's lymphoma & 107 & 0.26 & 9 & 1.12 & $0.21-2.63$ \\
\hline Melanotic macule & 90 & 0.22 & 4 & 0.64 & $0.22-1.26$ \\
\hline Pleomorphic adenoma & 90 & 0.22 & 14 & 0.70 & $0.27-1.29$ \\
\hline Nevus & 89 & 0.22 & 9 & 0.53 & $0.26-0.89$ \\
\hline Neurofibroma & 80 & 0.20 & 12 & 0.48 & $0.27-0.75$ \\
\hline
\end{tabular}




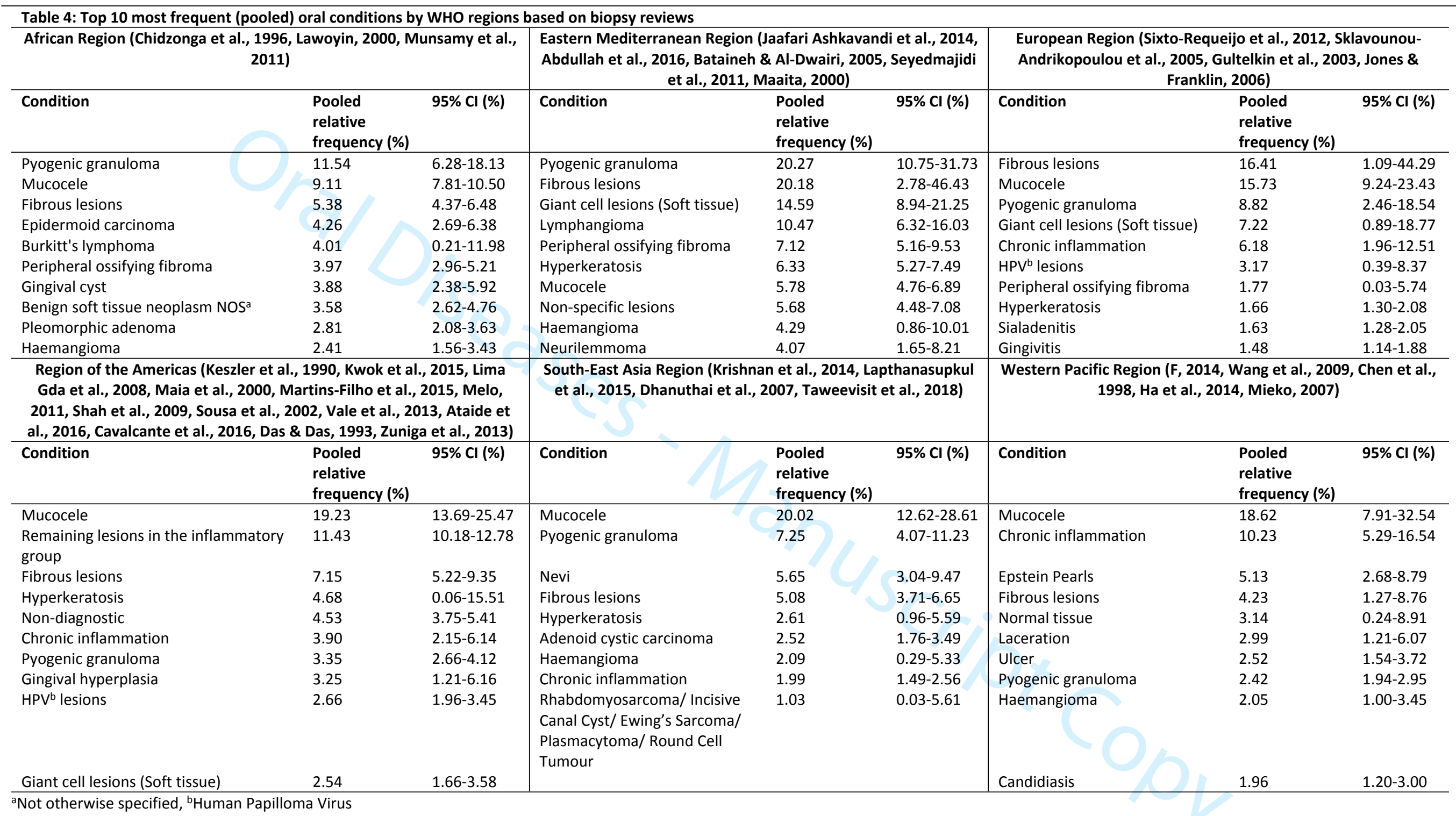


